\title{
Introdução a uma abordagem negativa da argumentação
}

\author{
Introduction to a negative approach in argumentation
}

\section{Julio Cabrera}

Universidade de Brasília - UnB - Brasília - Brasil

\begin{abstract}
Resumo: Existe uma abordagem predominante no campo da argumentação filosófica segundo a qual discussões podem ser decididas argumentativamente em favor de uma das partes. A abordagem negativa sustenta que cada parte de uma discussão tem sua própria Gestalt do problema, dependente de seus pressupostos, premissas e formas de sequitur admitidas. Duas afirmações opostas sobre o mesmo assunto (por exemplo, aborto) podem ser ambas verdadeiras. Defende - se um tipo particular de "relativismo objetivo" à luz da abordagem negativa da argumentação.
\end{abstract}

Palavras-chave: Lógica afirmativa - Lógica negativa - Argumentação - Relativismo

Abstract: There is a prevailing approach in philosophical argumentation, that I call affirmative, which sustains that discussions can be decided in favor of one of the parties. The negative approach states that each side has one own Gestalt of the problems being discussed, relative to its presuppositions, premises and forms of sequitur admitted. Two opposite statements on the same issue (for example, abortion) may be both true. A kind of "objective relativism" is defended in the light of the negative approach in philosophical argumentation.

Keywords: Affirmative logic - Negative logic - Argumentation - Relativism 


\section{Preliminares a partir de uma insatisfação não apenas metodológica}

Nesta altura da minha trajetória de pensamento, depois de ler acerca de múltiplos debates filosóficos ao longo de toda a história da filosofia europeia, e de participar pessoalmente de numerosos encontros, colóquios, congressos e seminários sobre debates filosóficos clássicos e contemporâneos, vejo como fortemente implausível que alguém - mesmo um competente estudioso da sua matéria - se disponha a apresentar as suas ideias sobre qualquer tema filosófico (ético, lógico, epistemológico, metafísico, político) pretendendo que as suas colocações sejam algo mais do que apenas uma perspectiva no meio de centenas de outras perspectivas possíveis sobre os assuntos debatidos. Resulta implausível que um pensador do século XXI ainda suponha que o que ele apresenta seja a solução ou a única resposta correta para as questões propostas, e que todas as outras estejam "erradas" e devam ser abandonadas em benefício daquela que ele propõe. (E não apenas erradas, mas também néscias ou desonestas, segundo seja o teor dos discursos, a veemência das discussões e a boa educação dos participantes).

Além de continuar numerosas disputas filosóficas da tradição europeia (acerca do ser, do devir, de Deus, da leitura da Bíblia, da natureza do mal, dos universais, da dúvida, do estado de natureza e o contrato social, da questão da crítica e superação da metafísica, etc.), as filosofias do século $X X$ continuam se digladiando em disputas infindáveis, apenas conseguindo colocar de maneira mais clara e rigorosa as diferenças e oposições entre posturas (mesmo em áreas tão precisas quanto a filosofia da matemática, onde surgem várias teorias, nenhuma delas absolutamente optável, de fundamentação da matemática), sem fornecer-Ihes soluções únicas. Isto mesmo se vê nas disputas entre Heidegger e os neokantianos, Carnap contra Heidegger, Russell e Frege, Wittgenstein e Russell, Frege e Kripke, Popper e Adorno, Popper e Kuhn, Apel e Habermas, Rawls contra Nozick ou Maclntyre, Chomsky contra
Wittgenstein, Searle vs Derrida, Rorty e os fundacionalistas, e assim por diante.

Muitos "grandes filósofos" europeus já apresentaram as suas queixas diante do caráter interminável e inconcluso das discussões filosóficas, se comparadas com as discussões na ciência. $O$ principal deles foi Kant, quem considerou, nos "Prolegómenos", como um "escândalo" o espetáculo da diversidade de filosofias e a sua "falta de acordo" pelo menos em torno de algumas poucas verdades consensuais, o que ele via como sinal de uma "imperfeição" da filosofia (ou, em seus termos, da metafísica) e que lhe impede progredir e entrar regiamente no "seguro caminho da ciência". Ele aponta que enquanto as ciências progridem, aquela que se dá a si mesma o título de sabedoria máxima continua dando voltas sem avançar um passo sequer ${ }^{1}$.

Mas essas queixas meta-filosóficas acerca das intermináveis disputas entre filósofos pressupõem uma atitude que parece ser a mesma que a dos filósofos criticados: cada filósofo pensa ter, finalmente, atingido a verdade única descartando as alternativas, e é precisamente o fracasso desse propósito o que provoca as queixas de Kant e os outros. Esta maneira de apresentar as filosofias facilita uma posterior decepção. Embora se possa ler a filosofia crítica kantiana como uma tentativa de desmascaramento do discurso filosófico anterior, afinal de contas o próprio Kant pensa ter achado finalmente "a solução correta" aos problemas (e conseguiu ainda ficar indignado diante de "deturpações" de seu pensamento). Assim como Kant pensava que os filósofos morais gregos estavam equivocados quando colocaram a moralidade como busca da felicidade, Max Scheler achava que o

\footnotetext{
1 Outros exemplos desta mesma queixa são, por exemplo, Max Scheler quando escreve: "...opera contra a validade objetiva de uma determinada captação do mundo o fato de que se desenvolveu historicamente um número ilimitado de sistemas metafísicos do gênero, e que estes se têm afrontado, excluído e combatido reciprocamente em todo o tempo, sem chegar até hoje a alguma decisão" (Citado por D'Agostini F, p. 238). Também Bertrand Russell manifestou várias vezes seu desgosto diante do fato da total discordância entre os grandes filósofos, de tal modo que entrar na história da filosofia era como mergulhar num caldeirão cheio de todas as ideias imagináveis.
} 
materialismo estava errado e Russell que o intuicionismo bergsoniano era nefasto.

Nisto tudo eu vejo a vigência de certo tipo de abordagem da argumentação filosófica que vou chamar aqui de "abordagem afirmativa", consistente em pensar que as questões filosóficas têm solução, ou, pelo menos, um tratamento adequado diante de centenas de outros que seriam inadequados; solução ou tratamento que sistematicamente seria aportado por uma postura (em geral, a própria), soterrando as outras no erro, na ignorância ou em coisas piores (desonestidade, má fé, etc.). O que vemos, inclusive nos considerados "grandes filósofos" da época clássica e atual, é uma concentração total na própria posição, crença de estar fornecendo a visão adequada das questões debatidas e condenação, às vezes sumária, das alternativas.

Se adotarmos o ponto de vista "afirmativo", resulta pelo menos estranho que, durante tantos e tantos séculos, não se tenham ainda "descoberto" as "soluções" para os problemas filosóficos (o que é conhecimento, qual o fundamento da moralidade, o que é sentimento estético, etc.). Poderemos continuar, em pleno século XXI, encontrando explicações para esse fato na "falta de perspicácia" dos filósofos ou na "complexidade intrínseca" dos problemas? Parece possível começar a pensar que, talvez, não "há" problemas filosóficos da maneira como "há" cadeiras neste quarto, ou que não há nada para "descobrir" em filosofia no sentido de haver algo para descobrir na fraude de uma empresa construtora.

Esta preocupação meta-filosófica acerca da diversidade das filosofias foi o que me levou a tentar formular o que denomino uma abordagem "negativa" da argumentação (embora esta denominação seja recente em minhas investigações lógicas) ${ }^{2}$, em contraposição à abordagem "afirmativa" em vigor. A abordagem negativa pretende mostrar e desenvolver a atitude lógica que assumimos quando apreendemos

\footnotetext{
2 Esta terminologia de "afirmativo" e "negativo" é tipicamente uma terminologia-escada que pode ser utilizada por enquanto, numa primeira etapa da reflexão, mas que mais tarde haveria que dispensar. "Afirmativo/negativo", tanto em ética quanto em lógica, faz parte de um vocabulário efêmero.
}

a olhar em roda e descentralizamos a nossa postura em sua pretensão de ocupar o lugar privilegiado da verdade, preferindo colocá-la dentro de uma enorme rede holística de perspectivas. Do ponto de vista negativo, estas abordagens não se desalojam de maneira absoluta, embora cada postura possa criticar radicalmente as outras desde a própria perspectiva e sob seus próprios pressupostos. O fato de cada postura estar certa da própria correção e da incorreção das posturas contrárias - no meio do fato espantoso de uma multiplicidade de posturas todas elas manifestando essa mesma atitude - me parecia conter um poderoso elemento de autoengano que merecia uma profunda consideração meta-filosófica acerca do que realmente está acontecendo em nossas práticas argumentativas.

O que eu via quando me envolvia em discussões éticas (sobre procriação, aborto ou pena de morte) ou lógicas (sobre significado, lógicas não clássicas ou conexões lexicais) era que as posições do adversário eram perfeitamente sustentáveis, que apenas não eram as que eu mesmo preferia assumir. Ao mesmo tempo, via como perfeitamente sustentável o que eu colocava, mesmo diante de numerosas objeções. Duas pessoas pensantes que se põem a discutir sobre questões filosóficas vão diferir em praticamente tudo. Que sentido tinha continuar tentando impor a própria perspectiva como sendo a única correta? Eu não via motivo algum para tentar destruir o que os outros tinham pensado nem queria, eu mesmo, que o que eu conseguisse pensar sobre questões éticas ou lógicas fosse simplesmente destruído pelas posturas contrárias, como sendo absurdo, insustentável ou desonesto. Isto me parecia envolver uma importante questão de ética da argumentação.

\section{Os passos elementares de uma argumentação qualquer (Uma caracterização mínima)}

Como estamos a falar em argumentação, cabe, para início de conversa, tentar lembrar aquilo 
que qualquer leitor interessado em lógica ${ }^{3}$ deve poder encontrar em algum dos numerosos textos disponíveis: quais são os passos elementares de uma argumentação em geral. Esta será nossa tarefa nesta seção. Logo a seguir, cabe tentar caracterizar, de modo mais claro, o que seja uma abordagem "afirmativa" da argumentação filosófica ${ }^{4}$, que eu acredito seja a predominante, e não apenas no mundo ocidental (seção 3), para, a seguir, apresentar o que seria uma abordagem "negativa" (seção 4). Tratar-se-ia de ver quais seriam as atitudes afirmativa e negativa diante desses passos elementares de uma argumentação em geral. É claro que nem todas as passagens inferenciais são legitimas e a lógica existe, precisamente, para tentar avaliar - de maneiras diversas - a boa ou má qualidade de argumentos. Mas trata-se de ver como acontecem essas avaliações, as suas condições e limites.

Os passos de qualquer argumentação poderiam ser expostos no seguinte esquema geral:

(1) Existência do argumento. O primeiro a ser feito é ver se há realmente um argumento. Pois poderíamos estar apenas diante de um conglomerado desestruturado de afirmações onde nada se segue de nada. Poderia tratar-se de um relato meramente descritivo, de uma declaração de intenções ou de um desabafo emocional, embora aconteça às vezes que algo que aparece como mera descrição (por exemplo, as condições de vida numa prisão) carregue implicitamente um argumento. Às vezes tem sido indicada a presença de certos

\footnotetext{
${ }^{3}$ Refiro-me especialmente à lógica informal, por ser aquela em que as argumentações filosóficas se desenvolvem. Entretanto, uma boa parte do que será dito sobre lógicas informais aplicarse-ia mutatis mutandis também a lógicas formais. Pois esquemas argumentativos informais e formas lógicas estão imbricados de maneiras muito estreitas. Infelizmente, não poderei mostrar aqui este ponto.

4 Falo aqui exclusivamente de argumentação filosófica, e não de argumentação científica, por exemplo. A pesar de ser aceitável a postura de não haver uma demarcação demasiado nítida entre ciência e filosofia (como, por exemplo, Quine sustenta), prefiro diferenciar aqui uma discussão sobre mecânica quântica e uma discussão sobre relativismo moral. Tudo o que vou afirmar neste prefácio refere-se apenas a discussões do segundo tipo. Se uma parte ou tudo o que afirmo aqui sobre argumentações filosóficas se aplica também no plano da ciência (como textos de Kuhn e Feyerabend sugerem), tanto melhor; mas não serei eu a tentar provar essa tese mais larga.
}

termos (tais como "portanto", "então") como critério da presença de um argumento, mas há textos argumentativos onde essas palavras não aparecem, e textos com esses termos que não são argumentos.

(2) Existência de um argumentador. Não é suficiente com haver um argumento, tem também que existir alguém que o apresente e o defenda; que assuma o ônus da prova e se responsabilize pelo andamento da argumentação. Os critérios para decidir isto são diversos (por exemplo, o caráter antiintuitivo de algo que se quer provar, como, digamos, ser imoral ter filhos ou que matar pode ser moral). Também é importante que o arguidor estabeleça neste passo os propósitos da sua argumentação (demonstrar, refutar, reforçar, chamar a atenção, elogiar, escandalizar) e também qual será seu públicoalvo (todo mundo, os jovens, a comunidade dos filósofos, etc).

(3) Reconstrução do argumento. Se há um argumento (passo 1) e alguém se responsabiliza por ele (passo 2), então essa pessoa tem que tentar reconstruir o argumento mediante algum esquema, mostrando: se há um único argumento ou se há vários, qual é o argumento central, se algum argumento é subargumento de algum outro, quais as premissas e quais as conclusões esperadas, se as premissas estão numa sequência apropriada, etc. Este é um passo, em certa medida, "artesanal", como o do escultor que tira a estátua da pedra em bruto; aqui a pedra seria o texto dado real, e a estátua o argumento reconstruído.

(4) Clareza dos termos e valor de verdade das premissas. Tem que perguntar se na reconstrução feita no passo 3 há termos que precisam ser esclarecidos ou melhor definidos; também é necessário explicitar os pressupostos que estão sendo assumidos e quais as premissas cuja verdade será aceita sem argumentação. Ambas as coisas estão 
conectadas porque pode acontecer de aceitarmos a verdade de uma premissa quando os termos são entendidos de certa forma, e rejeitá-la como falsa com outras definições desses termos. Também tem que ser checado se as premissas e pressupostos assumidos não têm mais força do que a conclusão que se pretende obter com eles (por exemplo, numa discussão sobre se o aborto é eticamente legítimo, alguém não pode pretender que a outra parte aceite que os fetos não são pessoas, ou que Deus considera a vida sagrada, pois estes pontos são ainda mais controversos que o que se pretende provar com eles).

(5) Correção do argumento. Aqui chegamos ao núcleo mesmo da questão: as conclusões se seguem efetivamente das premissas e pressupostos assumidos? Qual a qualidade e confiabilidade da passagem inferencial? $\mathrm{O}$ argumento é convincente, contundente, estabelece a sua conclusão? (As maneiras de "seguir-se de" são múltiplas: dedutivas, indutivas, abdutivas, lexicais, retóricas, associativas, etc.).

(6) Propósito do argumento. Poderia pensar-se que o passo 5 é o último, mas não é assim: o argumento pode ter passado com sucesso o passo 5 e ser considerado um bom argumento e, não obstante isso, não ter conseguido alcançar o propósito que fora estabelecido para o argumento no passo 2, assim como não afetar ao público-alvo que tinha sido mirado nesse passo. Se isto não for atingido, o argumento fracassou, mesmo sendo um bom argumento segundo os critérios do passo 5 . 0 assentimento da audiência pode ser fundamental em muitos tipos de argumentação, e talvez em todos.

Podemos considerar estes seis passos como os indispensáveis para caracterizar minimamente um corpo argumentativo. Deve-se diferenciar este esquema elementar, em sua formalidade metodológica, de alguma específica teoria da argumentação (como, por exemplo, as de Stephen Toulmin, Alec Fisher, Carlos Vaz Ferreira, Douglas Walton ou Frans Van Eemeren). Pois seria difícil imaginar uma teoria da argumentação que não transitasse, de uma maneira ou outra, por esses seis passos.

\section{A usual abordagem afirmativa da argumentação}

A abordagem afirmativa da argumentação sustenta, basicamente, que aplicando algum procedimento que siga esses seis passos se poderá decidir conclusivamente acerca da correção ou incorreção de um argumento, estabelecendo um resultado e descartando outros como equivocados. Esta abordagem pode ser assumida de uma maneira mais forte ou numa versão mais fraca. A maneira fraca admite que os resultados atingidos pela argumentação não são absolutos e definitivos, mas sempre revisáveis. O arguidor afirmativo em versão fraca aceita que se pode voltar a um argumento, analisá-lo novamente e corrigi-lo, e que as conclusões obtidas podem não ser definitivas. Mas ele, de toda forma, acredita que, em cada processo argumentativo, há algo que se pode mostrar como correto, de tal forma que outras linhas ficam como incorretas - ou mesmo falaciosas - devendo portanto descartar-se. Também pensa que os resultados obtidos podem permanecer como incontestáveis até não aparecerem contra-argumentos convincentes que os derrubem.

Para uma abordagem afirmativa forte, alguns argumentos são decisivos de maneira definitiva e quem os negar comete um erro que deveria ser admitido. Para esta abordagem, algumas posições já foram suficientemente estabelecidas, e é muito difícil, ou mesmo impossível, que elas venham a ser removidas. Pense, por exemplo, nos argumentos habermasianos que pretendem mostrar a superação definitiva das "filosofias da consciência" pelas "filosofias da linguagem", ou nos argumentos que sustentam a superação definitiva das visões metafísicas da natureza estilo Hegel. Também a 
postura que Tugendhat adota diante da fenomenologia de Husserl e Heidegger, superada, segundo ele, pelo paradigma analítico de uma maneira irreversível (tornando uma "perda de tempo" dedicar tanto esforço a uma corrente de pensamento "ultrapassada"). Como um corolário bastante claro, a abordagem afirmativa forte costuma acreditar também em "progresso" em filosofia, na base de certas posturas terem deixado definitivamente para trás outras posturas, que se tornaram inviáveis ${ }^{5}$. (É claro que um mesmo pensador poderá assumir uma postura afirmativa fraca diante de certas questões e uma postura mais forte em outras). Como veremos melhor mais adiante, a abordagem afirmativa fraca pode até se aproximar bastante de uma abordagem negativa em alguns pontos, mas sem nunca coincidir com ela. Mas a abordagem negativa será formulada em clara oposição, sobretudo, a abordagem afirmativa forte ${ }^{6}$.

Abundam exemplos de atitudes lógicas afirmativas fortes no panorama da filosofia contemporânea. No capítulo sobre aborto, em seu livro Ética Prática, Peter Singer declara: "Em contraste com a opinião corrente, a de que a questão moral do aborto é um dilema sem solução, vou mostrar que, pelo menos dentro dos limites da ética não religiosa, existe uma resposta inequívoca, e que os que assumem um ponto de vista diferentes estão

\footnotetext{
${ }^{5}$ Para defensores do Wittgenstein anti-mentalista, por exemplo, é incabível continuar sustentando posturas racionalistas como as de Chomsky, que ainda defendem estruturas mentais universais inatas "Pode afirmar-se, creio, que Chomsky simplesmente não percebeu a importância nem a profundidade nem as repercussões dos resultados atingidos por Wittgenstein. Seu modo de dar conta, numas quantas linhas, por meio de silogismos triviais, do que são decisivos resultados filosóficos, $o$ põe de manifesto" (Tomasini Bassols Alejandro, "Seguir uma regla: resultados wittgensteineanos y especulaciones chomskyanas", p. 75. Minha tradução do espanhol e meu sublinhado).

6 Talvez foi Leibniz quem, no período moderno, inaugurou a concepção afirmativa da argumentação quando, em torno de 1685, manifestou a ideia de que quando a lógica estivesse suficientemente desenvolvida, os problemas filosóficos e teológicos poderiam resolver-se simplesmente calculando, de tal forma que as disputas fossem decididas para um lado ou para outro. Uma espécie de otimismo lógico universal. No começo do século XX. Bertrand Russell e outros filósofos da época acalentaram o mesmo anseio de verdades absolutas e de fundamentos irremovíveis, possibilitados agora, segundo eles, pela nova lógica de raiz fregeana. Fábio Salgado, meu exaluno e colaborador, aponta outros antecedentes históricos importantes, como o Platão que combateu aos sofistas, e Raimundo Lúlio, em quem Leibniz teria se inspirado.
}

simplesmente equivocados" (SINGER Peter. Ética Prática, p. 147. Meu sublinhado). Expondo o pensamento do filósofo tcheco-alemão Ernst Tugendhat, o filósofo brasileiro Ernildo Stein escreve: "Tugendhat afirma que só nos podemos empenhar em defesa de uma posição filosófica quando tivermos examinado as mais importantes posições de outros sobre a mesma questão e as tivermos derrotado". Um trabalho filosófico produtivo se funda em argumentos sobre uma questão (...) para a qual temos os melhores argumentos ou as melhores razões. Não se trata simplesmente de um trabalho comparativo para ver quem tem as melhores razões, mas de trazer razões que se apresentam como comprovadas e por isso levem os interlocutores a ver a mesma qualidade nas razões que apresentamos e, portanto, terminam aceitando nossos argumentos. É a argumentação na Filosofia" (STEIN Ernildo. Inovação na Filosofia, p. 39. Meus sublinhados).

Um exemplo bem recente de jargão afirmativo é o prefácio de "Wittgenstein's Metaphilosophy", de Paul Horwich, onde o autor atribui a Wittgenstein ter determinado "a verdadeira natureza da filosofia", para, logo a seguir, afirmar que Wittgenstein foi "frequentemente mal interpretado" (Preface, vii), e que muitos comentadores "distorcem feio a essência do seu pensamento" (viii). Ele sustenta que a ideia de Wittgenstein ser um autor impreciso “...é errada $e$ presta um desserviço ao caráter racionalmente disciplinado do pensamento de Wittgenstein" (Id). O autor pensa que considerar a crítica ao significado como a ideia central da filosofia "é equivocado", que "...ao contrário, a sua metafilosofia é o real fundamento..." de seu pensamento $(x)$ e que a ideia comum de que Wittgenstein produziu duas filosofias "é errada" (xi). Este não é o estilo particular de Horwich, mas aquele que, habitualmente, os filósofos utilizam quando entram em discussões: eles chegam na arena filosófica para refutar teorias e ideias "falsas", rejeitar interpretações "equivocadas" e colocar as coisas "como elas realmente são".

Também nos textos de Lógica Informal encontraremos declarações de um claro viés afirmativo, mais ou menos forte. Já no início de seu 
livro "Lógica Informal", Douglas Walton declara: "O objetivo deste livro é ajudar o leitor a usar métodos críticos para avaliar de forma imparcial e razoável os pontos fortes e fracos dos argumentos"' . Sugere-se aqui que podemos determinar de maneira isenta 0 que seja forte e o que seja fraco num argumento. Nesta visão afirmativa, um contra-argumento se entende como um argumento com a capacidade de ganhar do primeiro e derrubá-lo, removendo-o do caminho. No livro "Argumentation Schemes", que Walton escreveu junto com Reed e Macagno, já a formulação do procedimento informal apresentado é plenamente afirmativa: "O método de avaliação de um argumento que preenche um esquema consiste em que, uma vez que o argumento for colocado pelo proponente, ele pode ser derrotado (it may be defeated) se o respondente coloca uma questão crítica apropriada que não é respondida pelo proponente"8.

Aqui se reconhece que um argumento pode ser "derrotado", ou suas "falhas" serem postas de relevo através de uma "crítica adequada", como se estas questões não fossem controversas. Nesta mesma obra, encontramos muitas típicas formulações afirmativas, inclusive fortes, como: "Uma refutação derruba (knocks down) o argumento original" (220). "Um argumento que derrota outro é aquele que mostra que o outro argumento deve ser abandonado (...that the other argument has to be given up)" (224). (Ver também 229 e 247). "Se alguém não pode defender a premissa desse modo, seu argumento colapsa (...his argument collapses)" $(252)^{9}$.

Outra típica teoria afirmativa da argumentação é a chamada teoria "pragma-dialética", formulada pelo holandês Frans Van Eemeren (VE) e colaboradores ${ }^{10}$ - Segundo esta teoria, o processo argumentativo começa quando é reconhecida por ambas as partes uma "diferença de opinião" que, de maneira razoável, pretende ser "resolvida no mérito" através da

\footnotetext{
${ }^{7}$ Walton (2006), p.1. Meu sublinhado.

${ }^{8}$ Walton et alia (2010), p. 3. Meu sublinhado e minha tradução do inglês.

9 Todos os sublinhados são meus. (Ver ainda sobre refutação em 267-268, 271).

10 Tal como exposta, entre outras, em Van Eemeren (1995) (2004) e (2010).
}

argumentação. Supõe-se que, durante o processo de argumentação, e seguindo uma série de regras, uma das partes acabará prevalecendo sobre a outra mediante um jogo de justificações, chegando numa "resolução" da questão em disputa, e fazendo com que a outra parte retire a sua postura e a considere derrotada. Tudo isto não é apresentado pelos autores como sendo formulado num plano puramente ideal, normativo ou prescritivo, mas como um fenômeno de comunicação verbal ao mesmo tempo descritivo e normativo. Segundo os autores, no estudo da argumentação "(...) devem integrar-se metodicamente as perspectivas descritiva e normativa sobre 0 discurso argumentativo"11.

Embora a concepção afirmativa fraca da argumentação admita que argumentos informais são revisáveis e canceláveis (defeasible), estes estão submetidos rigorosamente a regras, que permitem, a princípio, "resolver no mérito" argumentos em favor de uma das partes descartando a outra. Isto sugere que, diante de problemas filosóficos (éticos, bioéticos, lógicos, políticos, metafísicos), um argumentador afirmativo entra nessas disputas convicto delas terem uma solução - mais ou menos provisória, mas talvez definitiva - que a outra parte terá que aceitar, e de que é possível encontrá-la através de um método rigoroso de argumentação e análise, mesmo que se trate de métodos informais de argumentação onde nunca pode haver uma resolução apodítica das questões.

De um modo geral, uma abordagem afirmativa da argumentação assume as seguintes teses (embora as versões forte e fraca possam discordar sobre o sentido ou o acento posto em algumas delas): (1) Há uma única realidade, não muitas realidades, que pode ser apreendida pela linguagem e pelo conhecimento. (Tese ontológica). (2) Muitas teorias filosóficas tentam descobrir e descrever essa realidade, mas fracassam devido à complexidade das questões e às próprias limitações das teorias. (Tese epistemológica) (3) Algumas teorias são melhores do que outras, estão melhor construídas e melhor

\footnotetext{
${ }^{11}$ Van Eemeren (1995), p. 1. (Minha tradução do inglês).
} 
argumentadas, na medida em que "acertam" melhor naquela realidade única; as melhores teorias derrotam as piores na sua empreitada de aproximarse da realidade. (Tese lógica) (4) As melhores teorias, as que melhor refletem a realidade, são as que nós sustentamos, enquanto as teorias dos outros estão erradas ou são menos adequadas do que as nossas. Nós estamos sempre abertos a correções e dispostos a abrir mão da nossa postura no momento em que nos apresentem bons contra-argumentos, ao contrário dos nossos adversários, que se fecham dogmaticamente em suas posições. (Tese psicológica)

\section{A abordagem negativa da argumentação}

A abordagem negativa da argumentação não contesta a abordagem afirmativa no plano normativo, no âmbito do que a argumentação deveria ser. A abordagem afirmativa, especialmente a forte, consegue, sem dúvida, enunciar 0 que seria desejável que acontecesse, o que todos nós desejaríamos que fosse o caso: que as questões filosóficas pudessem ser decididas de uma maneira objetiva ou de maneira a satisfazer todas as partes em conflito. A abordagem negativa também tem esse desejo e mantém essa expectativa no horizonte. Apenas quer se aproximar daquilo que efetivamente ocorre nas argumentações reais, objetivo principal e explícito das lógicas informais ${ }^{12}$. Isto não significa abandonar os ideais normativos característicos de qualquer lógica - formal ou informal - mas sim acentuar de maneira significativa a dimensão descritiva da argumentação, vendo 0 que efetivamente fazem os argumentadores, sem considerá-lo sempre - platonicamente - como um mero "desvio" de normas ideais.

Nesse plano estritamente descritivo, podemos começar com o que frequentemente aparece numa singela fenomenologia da argumentação, em nossas abundantes experiências em congressos, encontros e debates filosóficos. O que costumamos ver nessas

\footnotetext{
12 Cfr. Fisher A. (2008), p. 23, Walton D. (2006), p. ix, Toulmin S (2001), p. 211, entre outros muitos.
}

situações são alegações muito vigorosas de ambos os lados, defesas ferrenhas dos próprios pontos de vista, reticência de qualquer reconhecimento da própria derrota e a capacidade, aparentemente inesgotável - pelo menos por parte de arguidores maduros - de continuar argumentando de maneira indefinida, ficando a decisão final para uma questão de preferência ou de autoridade, mais do que de estrita "culminação argumentativa". A imensa maioria das discussões fica em aberto, e as reuniões acabam porque o moderador assim o decide ou porque a hora do break chegou, e não porque algum dos adversários tenha conseguido "provar" a sua posição, ou convencer ao outro de retirar a opinião ou tese que tinha colocado no início. Em muitas reuniões, o ponto é tão controverso que os participantes lançam mão do recurso do voto, da mera contagem de mãos levantadas, para "decidir" uma questão que, livrada a seu próprio desenvolvimento interno, continuaria indefinidamente.

A partir de uma fenomenologia de atitudes, a abordagem negativa não pretende sustentar qualquer tipo de ceticismo "pós-moderno" acerca da impossibilidade de argumentar, mas, pelo contrário, que, em discussões efetivas, sempre é possível argumentar. Num viés afirmativo, cada parte está convicta de possuir os melhores argumentos e tenta impô-los à outra parte; e não parece haver nenhum âmbito neutro e objetivo onde possa ser decidido, de maneira incontestável, quais são realmente os "melhores argumentos" para resolver uma questão, nenhum espaço que não esteja, por sua vez, submetido a novas e novas argumentações, contestações e pedidos de justificação. Para determinar que um argumento é "o melhor" já tem que ter sido assumida uma perspectiva.

$\mathrm{Na}$ abordagem negativa, em cada um dos seis passos da argumentação (como expostos na seção 2 deste trabalho) sempre poderiam abrir-se novas e novas linhas de argumentação, derivadas do fato de pôr-se em dúvida algo que um desses passos pretendia estabelecer sem controvérsia. Tome, por exemplo, o passo 1, a existência mesma do argumento. Para certas perspectivas e pressupostos 
pode existir um argumento que não existe para outras perspectivas com outros pressupostos. A "existência" de um argumento não é um fato ontológico dado. Numa discussão sobre aborto, para um participante religioso pode nem sequer existir algo como 0 "problema do aborto", pois para ele é totalmente evidente a natureza criminosa do ato de impedir o desenvolvimento de um feto. Ele pode não ver ali nada para ser discutido. E para um existencialista camusiano pode não haver nada como "o problema de Deus" a ser enfrentado e resolvido.

Entenda-se: aqui não há ainda estritamente confronto argumentativo, mas a discussão nem sequer começa, pois uma das partes não reconhece a existência de um problema a ser discutido. Se a outra parte visualiza um problema e tenta mostrar ao religioso que há um problema, ele terá que apresentar argumentos para mostrar isso, o que lhe obrigará a criar outra linha de argumento. Ele queria discutir sobre aborto, mas primeiro ele se vê obrigado a discutir sobre se há algo como "o problema do aborto". A natureza interminável da argumentação mostra-se no fato de que quando estamos, em geral, tentando argumentar sobre $X$, aparece uma argumentação prévia que não nos deixa entrar em X, pois temos ainda que argumentar para mostrar que há um $X$ a ser discutido.

Vejamos este mesmo fenômeno no passo 2: quem vai assumir o ônus da prova, e também qual é o propósito e o público-alvo da argumentação. Suponhamos que, numa discussão sobre aborto, o proponente quer aceitar uma versão forte do princípio "Não matarás!", enquanto que o oponente aceita apenas uma versão prima facie desse princípio, para poder arguir mais tarde a favor do aborto. Com isso, ele entende que quem tem que assumir o ônus da prova é o proponente, que defende um princípio forte e "menos intuitivo". Entretanto, o proponente pode considerar que seu princípio não é "forte" (por ter outros critérios para decidir sobre força argumentativa) e que, portanto, não é ele quem terá de assumir o ônus, mas seu adversário. Se uma das partes quer convencer à outra de que seu princípio é o mais fraco, e, portanto, eximir-se do ônus da prova, terá que gerar um novo argumento para convencer a outra parte sobre isso. Temos aqui o mesmo fenômeno de antes: quando tentávamos nos envolver numa argumentação sobre $\mathrm{X}$, temos que nos demorar numa argumentação prévia, para mostrar quem é que deve arcar com o ônus de argumentar sobre $\mathrm{X}$. Pois os arguidores podem ter um desacordo, por exemplo, acerca do caráter "intuitivo" ou não do princípio defendido por cada parte. (É claro que as abordagens afirmativas também aceitam discussões sobre o ônus da argumentação, mas acreditam que estas discussões têm um acabamento).

O mais assustador é que nada garante que novas e novas argumentações não tenham que abrirse, antes de poder entrar propriamente no assunto a respeito do qual os arguidores pretendiam discutir. No passo 3, a reconstrução do argumento (se há apenas um argumento ou se há vários) poderá depender de muitos pressupostos. Para o pró-aborto, poderá haver uma passagem inferencial imediata da premissa do feto não ser pessoa para a possibilidade de eliminálo, enquanto que o anti-aborto poderá exigir uma longa argumentação para mostrar isso. No passo 4, o oponente pode declarar que não entende um termo (por exemplo, "misericórdia" ou "dignidade da mulher") que aparece como perfeitamente claro para o proponente. Isto está vinculado com a aceitação ou não de premissas como "Atos misericordiosos são fundamentais em situações terminais, mas não em situações iniciais". Palavras como "misericordioso" estarão claras ou não dependendo da organização e perspectiva do problema; mas o crucial é que, numa discussão sobre o caráter ético ou não ético do ato eutanásico, haverá talvez que gastar um tempo prévio durante o qual uma das partes tentará justificar argumentativamente seu uso do termo "misericordioso" e a consequente verdade das premissas que contenham esse termo.

No passo 5 , as conclusões serão consideradas "contundentes" em certas organizações do material argumentativo e não em outras; dependendo de qual seja o mecanismo inferencial que a configuração do problema de cada participante aceitar como "adequado". Não há uma "contundência objetiva", 
nenhum argumento é "contundente" em si mesmo. Na avaliação da premissa "Não se deve matar pessoas inocentes", numa discussão sobre aborto, a "contundência" do argumento vai depender do que for acentuado; se acentuado o desamparo do ser inocente perde-se uma boa parte da "contundência" do argumento de Singer em favor do aborto. Ter descoberto um argumento contundente não é, pois, suficiente, há que compreender essa contundência dentro da rede holística de argumentos. Trata-se sempre de uma contundência dependente.

Em qualquer momento do processo argumentativo pode surgir a necessidade de transformar o que era premissa em conclusões, as quais exigirão novas premissas. Em qualquer um dos passos desse processo podem abrir-se novas e novas argumentações e sub-argumentações. A este fenômeno chamarei absorção argumentativa. O fenômeno da absorção é, segundo a abordagem negativa, algo que afeta a qualquer método de avaliação de argumentos. A ideia é que os argumentos estão sempre disponíveis; pode-se argumentar com sentido e coerentemente inclusive sobre entidades fictícias ou sobre mundos possíveis extravagantes, ou defender posições que já foram abundantemente atacadas. A um argumento sempre é possível opor outro argumento (e a própria noção de "contra-argumento" deverá mudar numa abordagem negativa da argumentação). O que não significa que não tentemos avaliar, de alguma forma, a qualidade de nossos argumentos, mas sem que possamos supor que exista um âmbito não afetado por perspectivas, no qual argumentos possam ser "decididos" de maneira absoluta em favor de uma das posições e contra da outra ${ }^{13}$.

\footnotetext{
${ }^{13}$ É claro que sim podemos decidir taxativa e definitivamente muitas questões de fato, tais como, por exemplo, que hoje é terça-feira e não domingo, ou que uma determinada loja está aberta 24 hs ou fecha à meia-noite, que Lula Da Silva foi presidente do Brasil entre 2003 e 2011, que Cervantes, e não Goethe, é o autor de Dom Quixote, que Cate Blanchett, até o presente (2016) ganhou o Oscar duas vezes e não três, que Brasília é a capital do Brasil e a anterior foi Rio de Janeiro e que eu, Julio Cabrera, publiquei um livro chamado "A Lógica condenada" em São Paulo em 1987. É óbvio que todas estas questões são verdades absolutas, se a linguagem funciona como funciona e as coisas são como são. Elas não são questões controversas sujeitas a um processo argumentativo. A tese da abordagem negativa refere-se exclusivamente a questões conceituais, do tipo: os domingos são dias mais
}

Suponha que A e B discutem sobre pena de morte. A pode alegar que seu pai passou muito mal depois de voltar de uma execução (isto é narrado por Albert Camus no começo do seu famoso "Ensaio sobre a guilhotina") e apresentar isso como um argumento contra a pena de morte. B poderá alegar que isso é algo puramente emocional e não vale como argumento; que ele está de acordo com a pena capital porque um crime particularmente hediondo (como matar crianças para vender seus olhos no mercado de órgãos) merece uma pena capital duríssima. A pode replicar que esta suposta "prova" também é puramente emocional, baseada falaciosamente num exemplo particularmente tocante. $B$ replica que 0 argumento reconstruído não emocionalmente, é o seguinte: deve haver equivalência entre o crime e a pena; se o crime foi horrendo, a pena deve sê-lo também. A pode responder que isto não está moralmente fundado, mas se baseia num tipo de vingança disfarçada; e que se a equivalência fosse a ser preservada literalmente, então o correto seria arrancar os olhos do assassino e vendê-los no mercado de órgãos (e talvez dar o dinheiro obtido da venda para os pais da criança). B pode responder que o princípio de equivalência do crime e da pena tem que se manter dentro do razoável e do ético, sem colocar-se no mesmo nível do assassino. A pode replicar que é impossível determinar um ponto do castigo onde termina a moral e começa a crueldade e a vingança. $B$ pode responder que o fato de não ser possível determinar um ponto nítido não desqualifica o argumento da equivalência (enquanto $A$ pensa que sim, que o desqualifica).

Decidimos parar aqui não porque os argumentos tenham "resolvido" a questão a favor de algum dos dois lados, nem porque uma das partes tenha desistido da luta e retirado sua colocação,

produtivos que os dias da semana, as lojas 24 horas são mais exploradoras de seus funcionários do que as que fecham mais cedo, a presidência de Lula foi muito mais atenta às necessidades do povo do que as anteriores, Fausto é uma obra mais universal que Dom Quixote, Cate Blanchett mereceu seu segundo Oscar mas não o primeiro; mudar a capital do Brasil do Rio para Brasília foi um retrocesso político, o livro "A lógica condenada" de Julio Cabrera foi uma contribuição relevante para a filosofia da lógica mas não para a lógica. 
reconhecendo que seu adversário tinha "os melhores argumentos", mas simplesmente porque nos cansamos e não queremos continuar, podendo perfeitamente fazê-lo, ou porque nos deparamos com algum recurso autoritário (uma instituição, uma lei, a força de um cargo, a "comunidade de especialistas", a "opinião da maioria", o "senso comum", etc.) para fazer artificialmente calar o nosso adversário (ver seção 5). As discussões filosóficas aparecem, na abordagem negativa como virtualmente intermináveis.

Enquanto na abordagem afirmativa se pensa que os arguidores se enfrentam em torno de uma mesma questão controversa e que um deles predomina sobre o outro por ter argumentos mais fortes e contundentes, na abordagem negativa todos os argumentos apresentam pontos fracos e insuficiências que os contra-argumentos sempre podem pôr de relevo e contestar. Mas isto indica que, nesta abordagem, 0 fato de apresentar contraargumentos contra uma posição filosófica não a desautoriza nem refuta, mas apenas a situa dentro de uma rede de argumentos na qual criticará argumentos e será criticado por outros. Na abordagem negativa não procuramos argumentos que não admitam qualquer contra-argumentação, mas argumentos cujas contra-argumentações possamos enfrentar melhor, que não nos afetem demasiado e para as quais sejamos capazes de gerar novos contra-contraargumentos dignos de ganhar novas réplicas, e assim indefinidamente. $\mathrm{Na}$ abordagem negativa, um contraargumento tem apenas o poder de recolocar um argumento diante de outros dentro de uma rede de argumentos, ou de obrigar outro argumento a ser reformulado, mas não tem poder para eliminá-lo.

A abordagem afirmativa ainda insistirá em que é evidente que "nem todas as argumentações são igualmente boas ou más, fortes ou frouxas", de que "há argumentos particularmente frouxos e outros menos". A abordagem negativa responde que para afirmar isto se precisa lançar mão de critérios de correção. Estes critérios não são externos à discussão mas fazem parte dela; eles também poderão ser contestados pela outra parte, e quem os apresenta deverá justificá-los mediante novos e novos argumentos, que podem por sua vez ser contestados e assim por diante. Segundo os critérios de uma das partes, o argumento será convincente; de acordo com os critérios da outra parte, os mesmos argumentos serão frouxos ou mesmo insustentáveis. Isto é o que aparece em discussões reais. $O$ argumento de que o aborto é legítimo em situação de estupro é contundente sobre bases utilitaristas, mas fraco em bases deontológicas. O argumento pro eutanásia é forte assumindo um princípio forte de autonomia, sem o qual o mesmo argumento se apresenta como fraco, e assim por diante.

As preocupações, neste ponto, acerca de um possível "vale tudo", podem dissipar-se, em parte, se percebemos que para alguém se envolver numa discussão filosófica tem que ter sido capaz de construir cuidadosamente uma postura levando em conta os seis passos elementares de uma argumentação qualquer. Ou seja, terá que ter mostrado que, em sua perspectiva, existe a linha de argumentação na qual nos convida a entrar, e terá que ser capaz de construir tal argumentação de maneira que os outros entendam o argumento. Terá que tomar-se 0 trabalho de explicitar seus pressupostos, definições e premissas, mostrar que a sua arguição tem objetivos e um público-alvo e que admite certos tipos específicos de sequitur lógicos. Não pode apresentar-se despreparado no local da arguição, exibindo apenas um conjunto desestruturado de ideias ou questões. Mas se ele tomar todas essas providências, se passar por todo esse esforço, a sua postura não poderá ser destruída pelas posturas contrárias, mas apenas receber oposições ou contra-argumentos que limitem as suas pretensões de unicidade e universalidade ou lhe obriguem a retificações e reformulações.

$\mathrm{Na}$ abordagem afirmativa, há uma tendência a colocar afirmações taxativas, do tipo: "Sem qualquer dúvida, o aborto deve ser permitido quando a situação da mulher grávida é de total fragilidade e não poderá criar seu filho adequadamente". (Às vezes acrescentam-se frases retóricas como: "E ninguém poderá negar isto, a menos de mostrar total insensibilidade humana", e outros recursos de 
desqualificação de alternativas). Na abordagem negativa, este tipo de afirmação não é rejeitado, mas poderia ser reformulado utilizando-se um método de paráfrase que tornasse explícitos os pressupostos assumidos. Algo do seguinte tipo: [Sendo o argumento reconstruído da maneira $X$ ] [Partindo das ideias, normas e princípios $\mathrm{x}, \mathrm{y}, \mathrm{z}$ ] [Sendo os termos relevantes definidos da maneira a,b,c] [Aceitando os tipos de sequitur lógico $A, B, C]$ [Organizando as peças do problema - por exemplo, aborto - numa forma Y] e [Tendo o argumento o propósito $\mathrm{W}$ ], existe pelo menos uma perspectiva segundo a qual "Sem qualquer dúvida, o aborto deve ser permitido quando a situação da mulher grávida é de total fragilidade e não poderá criar seu filho adequadamente". Pois a abordagem negativa vê a abordagem afirmativa como o resultado de uma quase total inconsciência de seus próprios pressupostos.

Às vezes se apresenta a curiosa objeção de que tudo isto se aplicaria apenas às atitudes dos arguidores, mas não à "argumentação em si", à teimosia e vontade de confundir, e não "à arguição mesma". Isto parece sustentar-se num curioso platonismo. Precisamente, o ponto é que, especialmente em lógica informal, é factualmente impossível diferenciar estes dois níveis, mesmo que seja possível fazê-lo num plano teórico, pois a noção de "assentimento" torna-se, nessa lógica, absolutamente central. O outro sempre poderá dizer, mesmo de perfeita boa-fé e com convicção (sem nenhum propósito de "complicar as coisas" ou de prejudicar a discussão) que não está convencido pelos meus argumentos pelos motivos tais e quais. Não posso, diante dele, distinguir um plano dos "puros argumentos" do plano onde ele e eu, arguidores reais, estamos discutindo, discordando e aguardando o assentimento uns dos outros. O caráter interminável das discussões filosóficas responde a características internas da própria argumentação; sempre é possível contra-argumentar, mesmo que os argumentadores ajam de boa fé e tenham se disposto a argumentar seriamente, e não apenas a obstaculizar as discussões. (Uma das partes poderá visualizar a outra como teimosa e destrutiva, mas a outra parte pode negar tal coisa e declarar que está sendo perfeitamente cooperativa).

A comunidade de arguidores, para bem ou para mal, é a referência última. É por isso que as questões filosóficas - como acontece nos diálogos de Platão - ficam abertas. O esforço da abordagem negativa consiste em fazer com que cada parte reconheça os direitos das outras de desenvolver suas próprias linhas de argumento sem tentar reduzi-las à própria, nem muito menos descartá-las total e definitivamente como absurdas, mesmo que essas outras linhas caminhem em direções totalmente opostas à própria. Apenas desenvolvemos nossa própria linha como uma entre muitas, mostramos seu rendimento apreciando as suas vantagens e criticando outras posturas sempre desde a nossa, mas sem eliminá-las como outras possibilidades cujo rendimento pode ter inclusive vantagens sobre a nossa linha, enquanto que, em outros aspectos, a nossa linha poderá ser mais interessante.

Podemos, como fizemos antes no caso da abordagem afirmativa, tentar resumir as características mais gerais de uma abordagem negativa da argumentação: (1) Não sabemos o que seja a realidade nem se ela é algo único ou múltiplo; mas ela se apresenta como esfacelada a respeito das múltiplas maneiras - todas elas objetivas - de ser organizada. (Tese ontológica) (2) As diversas teorias filosóficas descobrem e desenvolvem diferentes aspectos da realidade mas só através de suas respectivas organizações. Nesse sentido, nenhuma delas fracassa, todas triunfam; apenas fracassam em sua tentativa de descrever uma realidade única. (Tese epistemológica). (3) Todas as teorias filosóficas são sustentáveis em seus próprios termos, e são sistematicamente erradas ou inadequadas nos termos das outras teorias. Isto responde aos mecanismos internos de cada organização, que se auto-sustenta rejeitando as outras organizações. (Tese lógica). (4) Nossas teorias são perspectivas entre outras, sem qualquer tipo de privilégio; elas não são as melhores por serem as nossas e o fato de nós as formularmos não as torna corretas, nem deveriam ser colocadas 
como baluartes de autoafirmação da nossa existência. Na perspectiva negativa, a impressão de que a própria teoria deve ser melhor e única, e que os outros estão enganados, é uma ilusão psicológica sem apoio lógico. (Tese psicológica).

\section{Acerca da resolução política de argumentos}

Apesar de que a argumentação é intrinsecamente interminável se considerada no puro mérito dos argumentos, os processos argumentativos, de fato, acabam alguma vez (assim como a flecha de Zeno chega no alvo apesar dos prognósticos dos teóricos). Só que o "acabamento" dos processos argumentativos acontece por meio de eventos naturais (doença ou morte de um dos arguidores) ou, mais frequentemente, através de ações sociais, ou de uma mistura de ambas. Alguns arguidores envelhecem e ficam cansados de argumentar, ou deixam de ter a energia suficiente para defender suas posições, ou simplesmente morrem. Nesse caso, os adversários ocupam o espaço que esse pensador deixou vago e aproveitam para impor seus próprios argumentos, já que o adversário não está mais ali para se defender. Os mortos se transformam em bonecos de ventríloquo a través dos quais os diferentes intérpretes os fazem falar o que cada um deles prefere ouvir.

Isto acontece também com os filósofos ao longo da história da filosofia europeia: é claro que existiriam contra-argumentos kantianos contra as críticas de Hegel, e contra-argumentos hegelianos contra as críticas de Kierkegaard, e contraargumentos schopenhauereanos contra as críticas de Nietzsche e contra-argumentos do Tractatus contra as críticas dos pós-analíticos. A ressurreição de qualquer um desses filósofos provocaria uma verdadeira catástrofe na "história oficial" da filosofia, e obrigaria a reescrevê-la toda novamente; pois o trabalho historiográfico se baseia no fato incontestável dos filósofos criticados não poderem mais responder, e é isso unicamente o que garante a possibilidade de escrever essa história de maneira linear, inclusive descobrindo nela "progressos" ou "avanços" que qualquer filósofo ressuscitado colocaria de imediato em questão. Os pensadores criticados não estão mais ali para se defender, mas outros poderão assumir a sua defesa e, no estrito plano dos argumentos, o processo argumentativo poderia continuar indefinidamente.

Uma das partes pode também prevalecer com o auxílio de alguma ajuda externa, de caráter político, que inclui elementos retóricos fortes e também o poder dos sentimentos, muito decisivos quando se trata de convencer um ser humano. Entretanto, a parte argumentativa continua sendo necessária, embora raramente seja suficiente. Não podemos impor politicamente qualquer argumento mal apresentado; mas argumentar bem nunca será suficiente. Teremos que contar com algo externo que imponha essa boa argumentação e não aquela outra. Os argumentos não vão "se impor por si mesmos". Mas, numa perspectiva negativa, este apoio pragmático-político é externo aos argumentos, e não deveríamos naturalizar o que constitui uma decisão cultural transformando-a numa "resolução" objetiva das questões debatidas. As comunidades hegemônicas têm poder para decidir que certa discussão acabou ou que não tem mais sentido continuá-la.

O caráter terminável ou interminável dos argumentos está também ligado a certo plano "jurídico" da argumentação, no sentido de que um arguidor pode sempre defender-se, mesmo que ele esteja literalmente acuado por bons contraargumentos $^{14}$. Mas chega um momento em que um juiz, por exemplo, decide que uma linha de argumentação condena um sujeito à prisão perpétua e aqui acaba, socialmente, o processo argumentativo. Ou uma comunidade de cientistas ou filósofos decide que certos resultados são socialmente úteis e devem ser considerados como "bem estabelecidos",

\footnotetext{
${ }^{14}$ Quando um arguidor se vê literalmente encurralado, com as costas contra a parede, costuma funcionar a mais lamentável das falácias pragmáticas, a que denomino "falácia ad indignationem": o arguidor, já sem saídas argumentativas, se indigna contra o adversário alegando que está sendo agredido ou ofendido, e sai abruptamente do terreno argumentativo (e, às vezes, até da sala, dando uma portada). A indignação do adversário pode, por isso, ser um excelente sintoma de termos "acertado no alvo" ou "tocado na ferida".
} 
recusando-se a continuar discutindo sobre eles. Não porque novos contra-argumentos não estejam disponíveis, nem porque os argumentadores, ainda vivos, não sejam capazes de utilizá-los, mas por algum tipo de decisão social que envolve algum recurso à autoridade. (Que ninguém mais fale, por exemplo, sobre "incomensurabilidade de paradigmas" não mostra que os argumentos de Kuhn tenham sido derrotados "no mérito", mas apenas que os membros da comunidade se cansaram ou perderam interesse nessa discussão).

Podemos ser silenciados através de coerções hoje em dia, extremamente "civilizadas" e cordiais, baseadas em "consensos da comunidade" de filósofos; estes decidem o que vale e não vale em filosofia, o que está ultrapassado ou não. Estes procedimentos comunitários podem hoje, e talvez em todas as épocas, literalmente "enterrar" um trabalho filosófico importante e inovador, desde alguma perspectiva sustentável. Podemos ter muito bons argumentos para defender um ponto, mas se tivermos a comunidade contra de nós não conseguiremos impô-lo. O que é um "bom argumento" é decidido pelas comunidades. Fatores psicológicos privam socialmente nas discussões, fazendo com que a parte que utilize melhor esses recursos de impacto psicológico (de reforço a certas linhas de argumento) se dará melhor que aquela outra que apenas apresenta argumentos sem esse reforço. (O mero fato de falar em primeiro lugar numa mesa redonda já pode colocar-nos num lugar de desvantagem, e muitos conferencistas, sabendo disso, pedem ficar no último lugar, para poder ter a última palavra sobre o assunto debatido).

Um problema permanente dos pareceres de comissões, corpos editorais, etc, é a confusão que constantemente se comete entre a sustentabilidade dos argumentos apresentados pelo texto a ser julgado, e o fato do parecerista achar contraargumentos ao mesmo. $\mathrm{Na}$ abordagem negativa da argumentação, sabemos que sempre haverá contraargumentos contra qualquer texto que for submetido para publicação, de tal maneira que o fato do parecerista achar contra-argumentos (alguns ou muitos) ao texto não é motivo para rejeitá-lo ou impedir a sua publicação. Em muitíssimos casos, o parecerista rejeita o texto alegando que a linha argumentativa é "fraca" ou "não convincente", pois, instalado, como habitualmente, na postura afirmativa, acredita que essas distinções são perfeitamente claras e nítidas e que ele, em particular, é capaz de distinguir entre uma "boa argumentação" e uma argumentação "fraca". Segundo a abordagem negativa, o único que o parecerista teria que julgar seria se a postura apresentada no texto é sustentável, não se ela enfrenta contra-argumentos. Mas a relação entre o autor do texto e o parecerista é assimétrica. Para todos os efeitos, os autores de trabalhos rejeitados são como mortos, não têm qualquer chance de rebater e defender seus textos. A discussão fica decidida por tratar-se de uma relação unilateral e sem apelações; os referees estão habilitados para fazer valer seus motivos e valores, mesmo que eles não levem em conta a perspectiva desde a qual o texto rejeitado foi pensado e desenvolvido.

60 background filosófico da abordagem negativa da argumentação: além de dogmatismo e ceticismo. Pluralismo, Gestalt e Relativismo objetivo.

\subsection{Acerca do caráter "gestáltico" das argumentações} na abordagem negativa

Os perigos de "subjetivismo" que rondam a abordagem negativa poderão dissipar-se acentuando o caráter gestáltico das argumentações, o fato de cada uma das partes da discussão organizarem os elementos do problema debatido de diferentes maneiras, mas sem que essas organizações sejam "subjetivas", pessoais, privadas, individuais, intransferíveis, incomunicáveis ou incomensuráveis, mas perfeitamente objetivas, só que diversificadas; simbolizadas e organizadas de maneiras diferentes. A teoria da Gestalt perceptiva, tal como desenvolvida a partir dos estudos de Wertheimer, Koffka e Köhler (hoje continuada nos trabalhos de L. Spillmann, I. Kóvacs, W. Singer, E. Scheerer e muitos outros) 
deveria poder deslocar-se para o plano conceitual. A ideia básica desta teoria é que a observação de objetos nunca é simples e mecânica, mas sempre organizada de certa maneira mediante uma série de leis de organização, que regem operações ou ações humanas, a maioria implícitas, tais como a aproximação, a semelhança, o distanciamento, a regularidade, a simetria, a simplicidade, a associação, a segregação, o preenchimento, a continuidade, a unidade, o fechamento, todas norteadas por uma espécie de meta-regra, a "pregnância", que organiza objetos baseada naquelas relações, unificando ou dissociando.

Precisamente por isso, podemos não ver algo que está na nossa frente, "em nosso nariz", porque a organização perceptual que nesse momento utilizo interdita essa organização. Não vemos tudo o que "está ai" para ver, mas apenas o que as nossas organizações nos permitem ver. Isto deve alterar a noção mesma de "experiência" que se utiliza em teorias ditas empíricas, pois é claro que a teoria gestáltica da percepção é uma teoria empirista; só que ela salienta que os dados da experiência não se "impõem" a nós de maneira linear e mecânica, mas que já nos aparecem organizados de certas maneiras e não de outras. Isto deve questionar a ideia da experiência ser uma espécie de tribunal único e confiável ao qual se pode apelar para decidir questões a favor de uma ou outra das partes, porque a própria experiência se apresenta plural e esfacelada, organizada de formas diversas pelas diferentes posturas. O que seja um "fato" deve também mudar. Não há fatos totalmente objetivos e dados, mas eles aparecerão em certas Gestalten e não em outras.

As Gestalten não são invenções puras, elas surgem de certo material dado; elas podem começar sendo algo muito difuso e indiferenciado, para depois transformar-se em organizações mais nítidas. Não há na teoria da Gestalt nenhum tipo de idealismo absoluto; os tijolos e materiais das Gestalten estão ali, mas nós não podemos vê-los a não ser dentro de organizações. De certa forma, há um realismo dos tijolos e um idealismo das construções (das casas, pontes, trincheiras, salões de chá, cortiços e palácios que se podem construir com eles). Como a pedra do escultor ou as imagens de cinema para o montador, as peças estão ali para serem esculpidas e editadas de milhares de maneiras diferentes. As Gestalten não são enigmáticas entidades intermediárias entre o olho e os objetos, mas a maneira como os objetos se dão à nossa percepção. Vemos os objetos, e não misteriosos representantes dos mesmos, porém sempre organizados de certa forma. Não há, pois, que postular qualquer "apriorismo gestáltico", nenhuma necessidade de um "transcendental". As Gestalten não são algo "a mais" além dos objetos, são os objetos mesmos organizados ${ }^{15}$.

A abordagem negativa da argumentação leva estas ideias do plano perceptual das observações para o plano das ideias, pensamentos e conceitos. Isto não quer dizer que a teoria da Gestalt forneça uma explicação acabada dos processos de pensamento. Trata-se de algo muito mais modesto: tomar consciência do pensamento conter uma importante componente gestáltica. Também o que pensamos é organizado segundo aquelas mesmas operações (poucas delas têm uma importância apenas perceptual). Quando dois arguidores se enfrentam para discutir, digamos, sobre aborto, em suas respectivas Gestalten da questão, elementos como "feto", "inocente", "pessoa", "nascimento", "violência", "interrupção", "autonomia", "corpo", "sofrimento", "matar", "processo", etc, estão organizados mediante aproximações, semelhanças, simetrias, distanciamentos e continuidades que são variadas (e é isso, basicamente, o que provoca os terríveis e irreconciliáveis confrontos entre as diversas posições). Uma Gestalt que aproxime interrupção de gravidez de assassinato e outra que os afaste, ou uma que dissocie totalmente violência de autonomia, jamais concordarão.

Não se trata primariamente de diferentes "interpretações", mas de algo mais primordial, anterior à interpretações, algo como as condições mais elementares para simplesmente poder ver os objetos

${ }^{15}$ Köhler (1980), pp. 19, 64. 
em jogo, de tal forma que o fato de não conseguir captá-los, mais do que um "erro de interpretação", deveria considerar-se como uma forma de cegueira. Cada um de nós está dependente (e mesmo totalmente presos) das nossas Gestalten, e apenas conseguimos ver o que elas nos permitem. Assim como é possível olhar sem ver e ouvir sem escutar, assim é possível tomar conhecimento de um conceito e não conseguir utilizá-lo nem pensá-lo nem ver a sua importância, porque ele está organizado de uma maneira tal que nos é estranha ou não nos estimula. Assim como, visualmente, certas organizações de peças oportunizam ou propiciam associações perceptuais, de maneira semelhante certas organizações de ideias oportunizam ou propiciam pensamentos. Pensem em casos como as aproximações que Zizek faz entre a Psicanálise e a cultura popular; ele está aqui propondo uma Gestalt insólita mediante a aproximação de dois elementos tradicionalmente muito distantes um do outro. Ou a aproximação heideggeriana entre Platão e a técnica. Ou a dissociação proposta por Kant entre religião e filosofia. Praticamente todas as inovações filosóficas são propostas de novas Gestalten baseadas naquelas operações sobre os pensamentos ${ }^{16}$.

As respectivas "cegueiras" dos participantes numa discussão a respeito de certas organizações de conceitos, ideias, experiências e intuições, torna as discussões verdadeiros confrontos entre cegueiras. Cada um olha a postura do outro sem vê-la, (e ouve ao outro sem realmente escutá-lo). Estas Gestalten que acompanham inevitavelmente aos participantes de qualquer discussão filosófica incluem definições de termos, cruciais para montar as premissas que aceitaremos ou rejeitaremos. Utilizo, por exemplo, numa discussão sobre eutanásia, o termo "desenganado" para referir-me ao simples fato de um doente terminal sem cura, mas meu interlocutor fica irado porque ele vincula esse mesmo termo com algo de pejorativo ou desprezível. Utilizo o termo "consumação" para referir-me a um doente terminal que "consumou" a sua condição humana, no sentido dela ter chegado a seu fim, mas o outro interlocutor

\footnotetext{
$\overline{16}$ Köhler (1980), pp. 84, 103-4, 119, 166.
}

afirma que isso é absurdo, porque ele utiliza o termo "consumar" como apontando para algo bom e desejável (que a situação de um doente terminal certamente não é). Ou utilizamos o termo "inocente" numa discussão sobre aborto, ou a palavra "vingança" numa discussão sobre pena de morte, em sentidos diferentes, ou com forças retóricas e afetivas diferentes.

Então, dentro da abordagem negativa, as argumentações são virtualmente intermináveis também porque cada argumentador, quando entra numa discussão, se apoia numa certa configuração ou organização (numa certa disposição figura-fundo das mesmas peças) da situação problemática (lógica, ética, metafísica, política) que está sendo discutida; o que inclui significados de termos, pressupostos, premissas, modos de sequitur lógico, acentuações, interesses e afetos. Estas configurações remetem a uma específica rede holística de pressupostos e crenças que nunca coincide totalmente com a dos outros participantes, mas que permite certa interação dinâmica entre Gestalten, baseada em superposições parciais aceitas, ou, pelo menos, conjecturadas, por ambas as partes. É claro que não há total incomensurabilidade entre Gestalten, porque, nesse caso, nem poderia nem mesmo haver "interação" entre elas. Essa interação, entretanto, dista muito de constituir uma bem-sucedida "comunicação"; apenas consegue constituir um intercâmbio frágil e parcial, conjectural e hipotético, com muitos tropeços, dúvidas, acomodações, retificações e mútuas incompreensões.

Pela força de poderosos mecanismos psicológicos e biológicos, cada um dos arguidores pensa estar com a razão, que a sua Gestalt coincide com o que o mundo "realmente é", e que seus interlocutores "se equivocam". É por isso que, à luz da concepção negativa da argumentação, as mencionadas queixas de "grandes filósofos" europeus diante do caráter interminável e inconcluso das discussões filosóficas, se comparadas com as discussões científicas, podem ser vistas, nesta perspectiva, como produtos de um poderoso engano, ao não conseguir esses autores visualizar uma das 
características mais recorrentes da atividade filosófica: a sua diversidade de aspectos ${ }^{17}$. Isto mostra como grandes filósofos podem ser péssimos meta-filósofos.

\subsection{Além de ceticismo e dogmatismo}

Gostaria situar a abordagem negativa da argumentação dentro do contexto da discussão entre dogmatismo e ceticismo. O dogmatismo adota uma atitude afirmativa de tipo monista, pensa que a verdade é una e universal (uma filosofia do "Todo"). Cada filosofia dogmática pensa ter atingido essa verdade-una e que as outras filosofias falharam na tentativa, estão erradas e devem ser eliminadas. O dogmatismo é, pois, heterocida ${ }^{18}$. O dogmatismo pensa que a verdade deve ser uma; multiplicidade é sinal de frivolidade, falta de seriedade e responsabilidade. Filósofos consagrados como KarlOtto Apel e Hilary Putnam consideram qualquer forma de multiplicidade relativista como "irresponsável". Nos termos de Tugendhat, não se filosofa como se dança, não se muda de filosofia como se muda de modos de dançar. O dogmatismo pensa que a seriedade e a responsabilidade estão do lado do Uno; o múltiplo é frívolo e irresponsável ${ }^{19}$.

O ceticismo, pela sua parte, a pesar de opor-se ao dogmatismo, é também monista e pensa que, de existir a verdade, ela deve ser una; mas como não existe essa verdade-una - dado o conflito irredutível das filosofias - então deve-se, simplesmente, suspender o juízo sobre a verdade do que está em jogo, ou mesmo parar de filosofar. Mas esta atitude drástica mostra que o cético partilha a concepção absoluta de filosofia do dogmático, pois a mesma filosofia-una que o dogmático acredita ter descoberto, é aquela mesma que o cético vê como inatingível, que o leva a suspender o juízo ou mesmo abandonar

\footnotetext{
17 "Mas se a controvérsia tem essa constante e marcante presença ao longo da história da filosofia, talvez isso não seja sinal da falta de maturidade de uma etapa pré-científica, mas um componente essencial da atividade filosófica". (Dascal M (2001), Introdução. (Minha tradução do inglês).

${ }^{18}$ Este é um termo que utilizo em meu pensamento ético, para referir-me ao causar a morte de qualquer outro ser humano diferente de mim mesmo.

19 Apel (1998), p. 14, Putnam (2008), p. 16, Tugendhat (1992), p. 14.
}

a filosofia. Entretanto, a desistência cética poupa a vida das outras filosofias; o ceticismo não é, pois, heterocida, mas suicida. E o ceticismo tem a sua própria "seriedade", pois pensa que como não existe a verdade-una, o sério consiste então em abster-se.

A postura assumida pela abordagem negativa da argumentação não é monista, e, nesse sentido, não pode ser nem dogmática nem cética. Por não ser monista, não pensa que nenhuma filosofia dogmática tenha atingido uma verdade-una, única e universal, mas, contra o cético, não pensa que isso seja um motivo para suspender o juízo ou parar de filosofar. A abordagem negativa não é monista, mas pluralista, no sentido de considerar - contra o cético - que cada filosofia dogmática triunfa em atingir a verdade; mas contra o dogmático - isso não leva a declarar que todas as outras filosofias sejam falsas. Contra o cético, as filosofias dogmáticas não fracassam, elas triunfam; mas, contra o dogmático, esse triunfo não é único, definitivo e excludente de outras filosofias que também triunfam. A abordagem negativa assume plenamente o pluralismo, que não é nem heterocida (porque não busca destruir as outras filosofias) nem suicida (porque não se poupa de emitir juízos e continuar filosofando), mas aponta para uma espécie de argumentação trágica, que renuncia a qualquer universalidade, unicidade e exclusivismo e se reconhece como filosofia entre filosofias.

A abordagem negativa sustenta que os arguidores numa discussão nunca estão falando estritamente da mesma coisa, porque é muito improvável empiricamente que dois debatedores coincidam na totalidade de seus pressupostos, premissas e Gestalten. Mas, por isso mesmo, tampouco há contradição entre eles, no sentido formal estrito, porque se duas posturas chegam aos resultados $A$ e não $A$, custa pouco esforço mostrar que os pressupostos, as gêneses argumentativas e os sequitur de $A$ não são os mesmos que os de não A. O que há de importante na teoria da Gestalt para o confronto entre dogmatismo e ceticismo, é que as Gestalten, as perspectivas e organizações conceituais não são nem "objetivas" - no sentido de "dadas" sem a intervenção das construções humanas 
- nem tampouco "subjetivas" no sentido de psicológicas, pessoais ou privadas.

Quando vemos os famosos desenhos que se tornaram famosos nas explicações da teoria da Gestalt, tanto o pato quanto o coelho, a velha e a jovem, as duas jarras e os dois rostos, etc, sabemos que todos eles são perfeitamente objetivos, de qualquer lado que se observe; qualquer pessoa pode, fazendo um esforço (perceptual ou conceptual) visualizar a outra figura. As duas figuras são objetivas, embora relativas a perspectivas; só podem ser vistas assumindo certa perspectiva, o que não as torna "subjetivas". Trata-se, pois, de algo intermediário entre objetivo (dogmatismo) e subjetivo (ceticismo), uma espécie de objetividade mediada por uma perspectiva, que só surge de uma maneira peculiar de observar. Sem este esforço as figuras não surgirão, mas aquelas que surjam serão perfeitamente objetivas.

É curioso que, em nossas comunidades filosóficas, se deixem ouvir muito mais os temores de "relativismo" (diante da ideia de diversas posturas, mesmo aparentemente opostas umas às outras, poderem ser todas verdadeiras), mas que não apareça tanto o temor diante da ideia contrária, muito mais assustadora, segundo a qual apenas uma postura é a verdadeira, e todas as outras são "erradas" (a verdadeira sendo a própria postura, claro). Historicamente os totalitarismos e fanatismos têm se constituído invariavelmente sobre certezas absolutas, não sobre dúvidas céticas. Os totalitarismos nunca foram céticos. Entretanto, a abordagem negativa da argumentação não leva para nenhum tipo de "relativismo subjetivo", mas, em todo caso, a um relativismo objetivo ou gestáltico. Também se poderia dizer que a abordagem negativa assume uma espécie de realismo gestáltico ou perspectivo.

No imaginário comum, e pela forte influência da filosofia grega e da sua distinção entre o "saber" e a mera "opinião", o objetivo é visto como sendo único, enquanto o subjetivo é muitas coisas; o saber tem que ser um, enquanto as opiniões são muitas (uma ideia gêmea àquela segundo a qual o que é eticamente correto é um, enquanto o errado é múltiplo) ${ }^{20}$. A abordagem negativa subverte isto: o saber está tão esfacelado e diversificado quanto a opinião, se o entendermos gestalticamente. 0 objetivo está tão esfacelado quanto o subjetivo, não há uma única objetividade, perspectivas diversas podem descobrir diferentes dimensões do objetivo ${ }^{21}$.

Apesar da soberba afirmação de Singer dele ter, finalmente, descoberto a solução definitiva do problema do aborto, podendo encerrar definitivamente a questão, a sua "demonstração" depende de muitas sub-argumentações possíveis (que ele prefere não "ver"). Seu argumento pró-aborto só consegue ser estabelecido se aceitarmos algum tipo de ética utilitarista segundo a qual o bem-estar dos seres humanos concretos está por cima de qualquer ideia abstrata ou metafísica de "pessoa humana" (algo que as tornaria "intrinsecamente valiosas"). Também depende da ideia de que o eticamente relevante é que os seres humanos não sofram dor inútil, e da tese de que um ser humano pode definir-se mediante um conjunto de propriedades relevantes bem determinadas (os famosos "indicadores de humanidade"). Também depende de certa definição muito específica dos termos "matar" e "inocente" na expressão "ser humano inocente", e da desativação da ideia da "potencialidade", no sentido de alguém poder ser potencialmente uma coisa num momento $t+1$, que Ihe daria direitos em $\mathrm{t}$.

Trata-se de um alto número de pressupostos sem os quais a conclusão "objetiva" e "definitiva" não decorreria. Qualquer arguidor que não aceite pelo menos um desses pressupostos, não aceitará os "resultados incontestáveis" de Singer. E contrariamente ao que ele afirma, os que não os aceitam não estão "simplesmente equivocados", mas

\footnotetext{
20 “...é possível errar de muitas maneiras (pois o mau pertence ao ilimitado...enquanto que o bom pertence ao Limitado); pelo contrário, acertar é possível de uma maneira só..." (Aristóteles, Ética à Nicómaco, Livro II, 6).

21 Á rigor, talvez soe demasiado metafísico declarar que "a realidade mesma" está esfacelada. Se poderia dizer algo mais fraco: que a realidade permite que diversos aspectos seus sejam captados desde diferentes perspectivas que não se desalojam. Não sabemos se "a realidade mesma" - seja isto o que for - está esfacelada, mas certamente sabemos que a realidade é algo que permite o esfacelamento das perspectivas.
} 
assumem outros pressupostos e Gestalten perfeitamente plausíveis, sustentáveis e racionais dentro da rede de argumentações. Singer ignora drasticamente todos os questionamentos e obstáculos da sua linha de argumento (por exemplo, as controvérsias sobre os "indicadores de humanidade") e é apenas dessa forma que ainda consegue alimentar a ilusão de ter "resolvido" o problema do aborto.

Com nossos argumentos podemos fazer muitas coisas: esclarecer, analisar, elucidar, ensinar, ajudar, tornar mais simples, cooperar. Mas também podemos utilizar a argumentação para destruir, para exterminar os adversários e oposições, tal como qualquer animal o faz com seus próprios recursos (dentes, garras, velocidade, etc.). Costumo chamar isto da "parte animal" da argumentação. Os argumentos têm sido assumidos como armas de guerra $^{22}$. Por que os humanos são incapazes de construir as suas perspectivas sem pretender destruir as outras, é um problema antropológico e metafísico importante, que eu tenho tentado responder desde a minha ética negativa ${ }^{23}$.

$\underline{6.3}$ Auto-referência como confirmação, não como refutação

Os que estão lendo este texto já estarão com a objeção da "autocontradição performativa" pronta para disparar. Como é hoje amplamente aceito nas comunidades filosóficas, todas as formas de "relativismo" são consideradas formas de "ceticismo" que se autocontradizem e auto-refutam, na medida em que essas posturas tentam estabelecer algo absoluto e defendê-lo com razões como sendo a verdade, com o qual contrariam a sua própria tese cética ou relativista. Este argumento foi recorrente ao longo da história oficial da filosofia, mas recebeu uma formulação clara e consolidada na comunidade por parte de Karl-Otto Apel ${ }^{24}$. A partir daí, a objeção da "autocontradição performativa" se utiliza como se

\footnotetext{
22 Cfr. Lakoff e Johnson (1986), pp. 40-41.

23 Especialmente na "Crítica de la Moral Afirmativa" (2014.1 ${ }^{\text {a }}$ edição de 1996).

${ }^{24}$ Apel (1998), p. 14
}

fosse absolutamente contundente, como a refutação definitiva de qualquer forma de ceticismo relativista. Este é um argumento que dispara quase que de maneira espontânea - como tantos outros em filosofia - como se o pensador tivesse ativado uma espécie de "piloto automático filosófico" que, em presença de certo tipo de teoria, dispara já sem a presença do pensador.

O que primeiro chama a atenção neste procedimento é a distribuição assimétrica de caridades argumentativas na aplicação do teste. Pois a auto-refutação parece tão clara (como o seria em expressões do tipo "Eu não estou dizendo nada neste momento"), que a figura do cético fica ridicularizada, reduzida a uma postura que somente um néscio poderia sustentar. Como é que ele não se dá por conta de estar se autocontradizendo de uma maneira tão evidente? $\mathrm{Na}$ "autocontradição performativa" encontramos uma transgressão de uma regra argumentativa que pode ser vista como lógica e ética ao mesmo tempo: entre considerar nosso adversário como um tolo e considerar que há algo que não entendemos, deveríamos sempre optar pela segunda alternativa. Como Quine declara, falando da tradução: "O senso comum por trás da máxima é o de que a tolice do nosso interlocutor, a partir de certo ponto, é menos provável do que a má tradução..." (Quine, Palavra e Objeto, cap. II, seção 13, p. 90).

No caso particular da abordagem negativa da argumentação aqui apresentada, os defensores da "autocontradição performativa" dirão que, neste texto, eu estive argumentando e tentando impor meu próprio ponto de vista sobre argumentação - a abordagem negativa - como verdade absoluta, com o qual a abordagem negativa "se refutaria a si mesma". A abordagem negativa seria tratada como se fosse uma postura cética (o que já mostrei que não é). Mas este teste não se aplica a um relativismo objetivo, pluralista e gestáltico como o assumido pela abordagem negativa. É claro que deve admitir-se abertamente que tudo o que foi dito aqui sobre argumentação na abordagem negativa tem que aplicar-se também na presente argumentação. Se não fosse assim, ela mesma seria uma refutação da 
própria abordagem negativa. A discussão entre as abordagens afirmativa e negativa da argumentação também está inserida dentro da rede de argumentos, e também possui pressupostos e admite contraargumentos. Isto significa que também aqui se poderá argumentar indefinidamente.

E precisamente porque esse é o caso, porque a abordagem negativa terá sempre contraargumentos relevantes do lado afirmativo, é que a tese da abordagem negativa fica auto-confirmada e não auto-refutada, pois ela aceita plenamente a autoreferência e a auto-inclusão. Não como uma "frivolidade" literária, mas, pelo contrário, como um compromisso seriamente levado até as suas últimas consequências. Não apenas a abordagem negativa aceita a auto-inclusão mas necessita dela imperiosamente, porque, caso contrário, se não se auto-incluisse, ela seria, sim, autocontraditória, porque ela mesma seria um exemplo de postura absoluta que ela recusa. Este confronto interminável entre abordagem afirmativa e negativa da argumentação estará ilustrando, ele mesmo, precisamente, as teses negativas.

Mas se a abordagem negativa se reconhece a si mesma como gestáltica e não absoluta, então também se poderia mostrar que nem toda postura filosófica é gestáltica, com o que se mostraria ser falso que toda postura filosófica é gestáltica. Mas isto seria ainda uma visão afirmativa da questão, que supõe que uma destas posturas deve destruir a outra. $\mathrm{Na}$ visão negativa, é claro que existe uma linha de argumento que pode mostrar que nem todas as posturas filosóficas são gestálticas; mas isto tampouco será verdade absoluta, mas apenas resultado de certa linha de argumentação sustentável desde uma perspectiva, tão sustentável quanto a que defende que toda postura filosófica é gestáltica. Sempre alguém poderá apresentar, mudando os termos, as premissas e os sequitur, uma postura segundo a qual existem teorias que não são gestálticas. Mas isto também será uma perspectiva entre as outras. Esta situação mostra que ambas as posturas podem ser argumentadas indefinidamente, sem que nenhuma delas possa simplesmente eliminar a outra.

De fato, há muitas críticas que se poderiam dirigir contra a abordagem negativa da argumentação. Algumas poderiam ser as seguintes: (1) Não é historicamente verdadeiro que a totalidade das discussões filosóficas sejam intermináveis. Muitas delas acabaram de maneira satisfatória pela própria força dos argumentos. (2) Não existe atualmente algo como a "postura afirmativa forte"; ninguém no panorama filosófico contemporâneo pretende estar sustentando "verdades absolutas". Está elipticamente pressuposto que sempre se fala desde uma perspectiva, pelo qual a tese perspectivista é trivial. (3). A noção de um "perspectivismo objetivo" é inconsistente; se algo é visto em perspectiva não pode ser objetivo. O mesmo se aplica à expressão "relativismo objetivo". (4) Apesar do arguido pelo autor, confundem-se permanentemente os planos dos argumentos com características psicológicas dos arguidores. O que pode ser interminável são as alegações de participantes facciosos, não a argumentação em si. (5) A transposição que se pretende fazer da teoria perceptual da Gestalt para o plano dos conceitos está mal fundamentada, e precisaria de muita mais argumentação. (6) A "abordagem negativa" apenas recapitula a tese do caráter tentativo e conjectural da argumentação informal e não aporta nada de novo. (7) Não é correto colocar qualquer resolução de argumentos no plano político. (8) Ao postular que toda postura filosófica é sustentável, a abordagem negativa leva a uma "tolerância" excessiva, permitindo que argumentos extremamente conservadores ou reacionários (como, por exemplo, os de Ernst Nolte em torno do nazismo) ganhem um lugar de legitimidade dentro da "rede holística de argumentos". Afinal de contas, a abordagem negativa da argumentação representa a lógica do liberalismo, recusando qualquer substância histórica efetiva e colocando tudo no mesmo nível, os argumentos dos opressores e os dos oprimidos.

A lista de possíveis "objeções" para por aqui apenas por decisão arbitrária, pois ela poderia estender-se indefinidamente. Mas é da maior 
importância perceber que se eu não estiver morto ou impedido de falar, posso, em qualquer momento, apresentar as minhas contra-argumentações para cada um destes oito pontos, e quem as escutar concordará ou não com elas, ficará da parte dos críticos ou da minha parte, e assim por diante. Mas o que temos é sempre argumentos e contraargumentos. Aqui se poderá dizer: uma teoria que tem tantas objeções e contra-argumentos não pode ser uma boa teoria. Mas, precisamente, o fato da abordagem negativa ser submetida a intermináveis objeções prova, precisamente, seu ponto. Pois a abordagem negativa sustenta que há sempre contraargumentos contra qualquer argumento. A apresentação de (1)-(8), longe de enfraquecer, de forma absoluta, a abordagem negativa, a confirma, embora limitando-a e obrigando-a a se defender e retificar.

Curiosamente, a única maneira de refutar a tese do caráter gestáltico da presente argumentação seria aceitá-la totalmente como sendo a verdade absoluta, com o qual ela própria seria a sua própria refutação, porque finalmente teríamos achado uma teoria - a aqui apresentada - que não depende de Gestalten. Na última frase de seu livro "Modos de fazer mundos", Nelson Goodman é consciente desta curiosa situação quando escreve: “...qualquer vislumbre de acordo universal sobre qualquer coisa significativa é excepcional. Os meus leitores poderiam enfraquecer esta última convicção pondo-se unanimemente de acordo com o curso de pensamento, um tanto tortuoso e, num duplo sentido, tentativo, que tenho aqui seguido" (Goodman (1995), p. 196). Mas, certamente, não existirá nenhum leitor que aceite totalmente a teoria de Goodman nem a teoria do caráter gestáltico da argumentação como verdades absolutas. E mesmo que alguém o fizesse, ao aceitar cada uma das minhas afirmações, essa pessoa não estaria provando que a minha postura é absolutamente verdadeira, mas apenas se poupando do trabalho, sempre possível, de desenvolver contraargumentos contra ela. Sua aprovação absoluta não seria fruto da iluminação, mas da preguiça.
Assim, ao assumir-se como uma perspectiva entre outras, a abordagem negativa não se autorefuta, mas, pelo contrário, se auto-confirma, porque nem mesmo ela é uma exceção ao que ela afirma (e como poderia sê-lo?). Por outro lado, a abordagem negativa mostra a finitude da argumentação humana e pretende assumi-la plenamente - contra as gigantescas (e irresponsáveis, podemos dizer?) pretensões da tradição europeia, de Platão a Russell, de pretender atingir um patamar de verdades absolutas e irrefutáveis - mostrando que a última realidade da argumentação humana é este lançar os próprios argumentos no incessante e rico fluxo vital do pensamento, sem qualquer pretensão de resolução definitiva.

\section{Referências}

APEL, Karl-Otto. Ética do discurso como ética da responsabilidade. Cadernos de tradução, n. 3, USP, São Paulo, 1998.

ARISTÓTELES. Ética a Nicómaco. Alianza editorial, Madrid, 2010 (7ª̣ reimpressão).

BASSOLS, Alejandro Tomassini. "Seguir uma regla: resultados wittgensteineanos y especulaciones chomskyanas". (Em: Wrigley Michael (Ed). Wittgenstein. Revista Manuscrito. Vol. XVIII, n. 2, Campinas, outubro 1995).

CABRERA, Julio. A lógica condenada. Hucitec. Edusp, São Paulo, 1987.

CABRERA, Julio. Margens das filosofias da linguagem. Editora da UnB, 2009 (1를 reimp).

CABRERA, Julio, Da Silva Olavo Leopoldino. Inferências lexicais e interpretação de redes de predicados. Editora da UnB, 2007.

CABRERA, Julio. Crítica de la Moral Afirmativa. Gedisa, Barcelona, 2014 (2ª edição).

D'AGOSTINO, Franca. Analíticos e continentais. Unisinos, São Leopoldo, 2002.

DASCAL, Marcelo, "How rational can a polemic across the analytic-continental divide be?" International Journal of philosophical studies. 9: 313-39, 2001.

FISCHER, Alec. A lógica dos verdadeiros argumentos. Ed. Novo Conceito, SP, 2008.

GOODMAN, Nelson. Modos de fazer mundos. Edições Asa, Porto, 1995. 
HORWICH, Paul. Wittgenstein's Metaphilosophy. Clarendon Press, 2013 (Reimpr).

KÖHLER, Wolfgang. Psicologia da Gestalt. Editora Itatiaia, Belo Horizonte, 1980. (2ª ed).

LAKOFF, George, Johnson Mark. Metáforas de la vida cotidiana. Ed.Cátedra, Madrid, 1986.

PUTNAM, Hilary. Corda tripla. Ideias e Letras, SP, 2008.

QUINE, Willard. Palavra e Objeto. Editora Vozes, Petrópolis, 2010.

SINGER, Peter. Ética Prática. Martins Fontes. São Paulo, 1994.

STEIN, Ernildo. Inovação na Filosofia. Editora Unijuí, ljuí, 2011.

TOULMIN, Stephen. Os usos do argumento. Martins Fontes, São Paulo, 2001.

TUGENDHAT, Ernst. Lições introdutórias à filosofia analítica da linguagem. Ed. Unijuí, ljuí, 1992.

VAN, Eemeren Frans, Grootendorst Rob. A systematic theory of argumentation. The pragmadialectical approach. Cambridge University Press, 2004.

VAN, Eemeren Frans. Strategic maneuvering in argumentative discourse. John Benjamins Publishing Company, 2010.

WALTON, Douglas. Lógica Informal. Martins Fontes, São Paulo, 2006.

WALTON, Douglas, Reed Chris, Macagno Fabrizio. Argumentation schemes. Cambridge University Press, 2010 (reprinted).

\section{COMO CITAR ESSE ARTIGO}

CABRERA, Júlio. Introdução à uma abordagem negativa da argumentação. Signo, Santa Cruz do Sul, v. 42 , n. 73, jan. 2017. ISSN 1982-2014. Disponível em: <https://online.unisc.br/seer/index.php/signo/article/view/7990>. Acesso em: doi: http://dx.doi.org/10.17058/signo.v42i73.7990. 